\title{
Inequality of Opportunity: The New Motherhood and Apple Pie?
}

\author{
Adam Wagstaffa* and Ravi Kanburb \\ a Development Research Group, The World Bank, 1818 H Street, NW, Washington DC 20433, USA \\ ${ }^{b}$ Charles H. Dyson School of Applied Economics and Management, and Department of Economics, Cornell \\ University, 301-J Warren Hall, Ithaca, NY 14853-7801, USA
}

\section{Revised March 2015}

\section{Acknowledgments}

The findings, interpretations and conclusions expressed in this paper are entirely those of the authors, and do not necessarily represent the views of the World Bank, its Executive Directors, or the governments of the countries they represent.

* Corresponding author: Adam Wagstaff. Development Research Group, The World Bank, 1818 H Street, NW, Washington DC 20433, USA. Tel: +1 202473 0566, awagstaff@worldbank.org 
The recent paper by García-Gómez et al. (2014) in this journal is part of a rapidly growing industry aiming to quantify - and hence give some policy teeth to - the concept of inequality of opportunity. The idea behind the concept is simple yet powerful. Not all inequality is bad. The bad bit of inequality ('inequality of opportunity') is the part that emerges because of factors over which we have no control (our 'circumstances'). By contrast inequality that emerges because of our different choices and efforts (holding constant our circumstances) is fine, and to be encouraged.

On the face of it, questioning the usefulness of inequality of opportunity seems about as wrongheaded as questioning the merits of family vacations, Thanksgiving or dessert trolleys. What's not to like about it? We argue below, as we have argued at greater length elsewhere (Kanbur and Wagstaff 2015), that the idea is not quite as useful as it might at first glance appear, and is in fact rather dangerous. But turned upside down, it might yet be useful.

\section{A simple idea - let's see some numbers}

For inequality of opportunity to be a useful idea for policy, we need an estimate of how much of observed inequality is due to inequality of opportunity - or at least an upper bound on this number. So, for example, if inequality in income is 50/100, we'd like to be able to say that at most 20 percentage points is due to inequality of opportunity. Policy should aim to get rid of at most these 20 percentage points, but shouldn't try to eliminate the remaining 30 percentage points.

The modern empirical inequality of opportunity literature owes much to the work of Roemer (1998). The debt to Roemer is acknowledged in the 2006 World Development Report (World Bank 2006) which sparked a series of empirical exercises within the World Bank, 
perhaps the most prominent being a book on Latin America by Paes Paes de Barros et al. (2009) (distilled recently into a two-minute video on the Bank's YouTube channel), but also scholarly research such as Ferreira and Gignoux (2011) and Brunori et al. (2013).

Stripping away the technicalities, and overlooking some differences in methods between the studies, these exercises by Paes de Barros et al. (2009) and others proceed broadly like this. Take a household survey. Decide on an outcome - it could be immunization coverage, or educational attainment, or income. Calculate the amount of inequality in the outcome in the data - let's say it's 50/100. Then identify in the dataset the variables that capture the influences on the outcome over which the person had no control - their 'circumstances.' Form groups (or 'cells') based on combinations of these circumstance variables. Calculate how much inequality there is across these groups. Let's suppose it's 20. This is inequality of opportunity. The residual (30) is legitimate inequality due to differences in effort - differences within the cells of people in similar circumstances.

\section{No man is an island}

Our outcomes do, of course, reflect our own efforts and decisions. But they also reflect other people's efforts and decisions, and we have little - if any -control over these. The outcome of an infant reflects entirely the efforts and decisions of her parents, but she has no choice in who her parents are. That means that all inequality in immunization coverage is unjust. For outcomes relating to small children then we don't need to go into a complicated decomposition exercise to figure out the share of inequality of opportunity in total inequality - it's 100\%. So it's odd that Paes de Barros et al. (2009) in developing their 'human opportunities index' do just that. 
As a child moves through infancy into childhood, parental influences diminish, but they don't cease - our parents' choices and efforts shape the way we think and behave, right through to adulthood in fact (cf. e.g. Cohen 1989). And other people's actions start to affect the choices and efforts that a child makes - their teachers and their classmates. Because children don't select their teachers or classmates, the choices and efforts of these people ought surely to be listed among the circumstances over which the child has no control. But in the work by Paes de Barros et al. (2009) on educational attainment at age 15, these factors are not explicitly included in the set of circumstances - only implicitly insofar as they are captured by family income and a crude place-of-residence variable (urban vs. rural). The estimates will thus miss out an important part of what Paes de Barros et al. and other inequality-of-opportunity advocates agree is part of inequality of opportunity.

\section{Luck and risk}

Most outcomes also reflect luck. In their work, Paes de Barros et al. (2009) argue that luck belongs with effort: "In an ideal world, inequality in outcomes should reflect only differences in effort and choices individuals make, as well as luck." (Paes de Barros et al. 2009 p.15).

To be sure luck would belong alongside efforts if we could eliminate risk from our lives and chose not to do so. But we cannot. Much of the risk we are exposed to is linked to activities we have to engage in to get through the day, if not survive. Often the risks involved are not known with certainty by the scientific community; when they are known, they are not always disseminated in an accessible way, and there are commercial pressures to ignore them. 
Diet is a good example. We have to eat to survive. Yet the 2010 Global Burden of Disease (GBD) study (Lim et al. 2012) finds that dietary risks account for more deaths worldwide than alcohol and tobacco combined. Commercial pressures encourage a default diet that poses risks to health, and we have to make a conscious and determined effort to eat in a way that lowers health risks. Doing so isn't straightforward. Given the attention they receive in the media, one might imagine the big culprits in relation to diet are too little polyunsaturated fatty acid, and too much processed meat, trans-fatty acids, sugarsweetened beverages and red meat. Yet these are not according to the 2010 GBD study actually the biggest causes of diet-related deaths worldwide: over six times as many deaths are attributable to people consuming too much sodium, and too little fruit, nuts, seeds, vegetables and whole grains.

True there are examples of where people unnecessarily and knowingly expose themselves to risk. Smoking is the classic example: information on the risks is widely disseminated and in a way that's very intelligible; and people smoke only for pleasure, not because it is essential to their survival. Shouldn't inequalities in health caused by smoking decisions be classified then as just? Not necessarily. There is a school of thought (Le Grand 1987; Le Grand 1991; Cappelen and Norheim 2005) that says that people should not be held accountable for bad luck ('brute luck' as Dworkin (1981a; 1981b) calls it) but only for unnecessary fully-informed risky behaviors ('option luck' in Dworkin's terminology). That might mean taxing tobacco, alcohol, sugar-laden beverages, red meat, etc. at a rate that generates enough revenue to cover the extra expected health care costs, but making sure that everyone - smokers and nonsmokers - receive whatever health care they need to prolong their life and increase its quality. 


\section{Talents}

Like luck, talents play a big role in shaping outcomes. In their work, Paes de Barros et al. (2009) put talents in with efforts as well: “Success in life should depend on people’s choices, effort, and talents, not on their circumstances at birth." (Paes de Barros et al. 2009 p.1).

This is also a controversial choice. We can think of ourselves as starting life endowed with innate talents, which we can cultivate during our life. The talents we start our life with affects where we end up. We're unlikely to become an accomplished concert pianist if we start life with no musical talent. Since we have no control over our innate talents, by lumping all talent with effort Paes de Barros et al. (2009) will, yet again, end up underestimating the true amount of inequality of opportunity.

\section{Giving the emperor some clothes}

In a survey, we will inevitably capture only a small subset of the influences on a person's outcomes that were genuinely beyond their control. We have no hope of capturing innate talents, the influences and choices of parents, classmates and teachers, and the effects of brute luck (as distinct from option luck). So although the point of departure of inequality of opportunity is that some inequality is good, and we want to come up with a statement to the effect that the bad part of inequality (inequality of opportunity) is at most $\mathrm{x} \%$ of total inequality, the approach of Paes de Barros et al. allows us to say only that inequality of opportunity is at least $\mathrm{x} \%$ of total inequality. If we're honest, we actually have no idea in their approach how big the good bit of inequality is. Even if we present the number $\mathrm{x}$ to the policymaker with the caveat that it's a lower bound estimate of inequality of opportunity, the policymaker will likely think of it as a point estimate. And given the whole thrust of the inequality-of-opportunity agenda is that not all inequality is bad, the 
message the policymaker will likely take home is that $100-\mathrm{x}$ percent of inequality in her country is good.

The approach of García-Gómez et al. (2014) avoids some of the defects of that of Paes de Barros et al. (2009), but not all. García-Gómez et al. do not rely on a residual approach but explicitly specify circumstance and effort variables: they allow for a residual, but partition only that part of inequality explained by their regression model. Explicitly saying what the effort variables are is attractive. Showing how the results change as different ethical positions are taken with respect to whether a variable is circumstance or effort is also attractive. Also attractive is the idea of partitioning only explained inequality, and not labeling either way that part of inequality not caused by circumstance or effort variables.

From a policy perspective, though, the approach of García-Gómez et al. still has shortcomings. Purging effort variables of the influence of circumstances is a heroic task and likely to be well beyond even the richest datasets, even those like the UK's National Child Development Study that follow individuals from birth. In any case, if it's accepted that unnecessary and fully informed risky behaviors should be penalized through the tax system, rather than through health care allocation decisions, inequalities in outcomes due to risky behaviors (even if purged of circumstances) still belong in the unjustified part of inequality. This means we're quite likely to end up with the (ethically relevant) effort variables being a null set, and we will end up labeling all explained inequality as inequality of opportunity, albeit necessarily a lower bound on true inequality of opportunity.

Exercises like those of Paes de Barros et al. (2009) and García-Gómez et al. (2014) might be more useful for policy purposes if we turned them upside down. What if instead of pretending we can give policymakers a sense of how much inequality is justifiable, we use 
these exercises to give policymakers a sense of how much inequality is unjustifiable, and acknowledge that we have no way (at least right now) of quantifying the amount that is justifiable? This is in fact just what researchers in education and health have been doing for years (cf. e.g. van Doorslaer et al. 1997; Filmer and Pritchett 1999). Notwithstanding claims to the contrary by García-Gómez et al. (2014), the authors of such studies don't claim to be measuring all inequality of opportunity, but aim simply to parcel out socioeconomic differences in outcomes. This part is important because it is the part of inequality that ought to be most amenable to policy, and therefore the part whose continued existence is most offensive to an egalitarian, including those who stop short of committing to equality of outcomes and limit themselves to equality of opportunity. Yes, we may also argue that inequalities reflecting differences in innate talents, brute luck, and so on are also unjust. But those differences are harder to neutralize through policy. If we can eliminate inequalities due to observed circumstances, we won't have eliminated all inequality of opportunity. But we will have eliminated at least some of it. And what's not to like about that? 


\section{References}

Brunori, P., F. H. G. Ferreira and V. Peragine (2013). Inequality of opportunity, income inequality and economic mobility: some international comparisons. The World Bank, Policy Research Working Paper Series, 6304.

Cappelen, A. W. and O. F. Norheim (2005). "Responsibility in health care: a liberal egalitarian approach." Journal of Medical Ethics 31(8): 476-480.

Cohen, G. A. (1989). "On the currency of egalitarian justice." Ethics 99: 906-944.

Dworkin, R. (1981a). "What is Equality? Part 1: Equality of Welfare." Philosophy and Public Affairs 10: 185-246.

Dworkin, R. (1981b). "What is Equality? Part 2: Equality of Resources." Philosophy and Public Affairs 10: 283-345.

Ferreira, F. H. G. and J. Gignoux (2011). "The Measurement of Inequality of Opportunity: Theory and an Application to Latin America." Review of Income and Wealth $\mathbf{5 7}$ 4: 622-657.

Filmer, D. and L. Pritchett (1999). "The effect of household wealth on educational attainment: evidence from 35 countries." Population and Development Review 25(1): 85-120.

García-Gómez, P., E. Schokkaert, T. Van Ourti and T. Bago d'Uva (2014). "Inequity In The Face Of Death." Health Economics: n/a-n/a.

Kanbur, R. and A. Wagstaff (2015). How Useful Is Inequality of Opportunity as a Policy Construct? Proceedings from IEA Jordan Roundtable on Shared Prosperity. K. Basu and J. E. Stiglitz. London, Palgrave McMillan.

Le Grand, J. (1987). "Equity, health, and health care." Social Justice Research 1(3): 257 274.

Le Grand, J. (1991). Equity and choice : an essay in economics and applied philosophy. London ; New York, NY, USA, HarperCollins Academic.

Lim, S. S., T. Vos, A. D. Flaxman, G. Danaei, K. Shibuya, H. Adair-Rohani, M. A. AlMazroa, M. Amann, H. R. Anderson, K. G. Andrews, M. Aryee, C. Atkinson, L. J. Bacchus, A. N. Bahalim, K. Balakrishnan, J. Balmes, S. Barker-Collo, A. Baxter, M. L. Bell, J. D. Blore, F. Blyth, C. Bonner, G. Borges, R. Bourne, M. Boussinesq, M. Brauer, P. Brooks, N. G. Bruce, B. Brunekreef, C. Bryan-Hancock, C. Bucello, R. Buchbinder, F. Bull, R. T. Burnett, T. E. Byers, B. Calabria, J. Carapetis, E. Carnahan, Z. Chafe, F. Charlson, H. Chen, J. S. Chen, A. T.-A. Cheng, J. C. Child, A. Cohen, K. E. Colson, B. C. Cowie, S. Darby, S. Darling, A. Davis, L. Degenhardt, F. Dentener, D. C. Des Jarlais, K. Devries, M. Dherani, E. L. Ding, E. R. Dorsey, T. Driscoll, K. Edmond, S. E. Ali, R. E. Engell, P. J. Erwin, S. Fahimi, G. Falder, F. Farzadfar, A. Ferrari, M. M. Finucane, S. Flaxman, F. G. R. Fowkes, G. Freedman, M. K. Freeman, E. Gakidou, S. Ghosh, E. Giovannucci, G. Gmel, K. Graham, R. Grainger, B. Grant, D. Gunnell, H. R. Gutierrez, W. Hall, H. W. Hoek, A. Hogan, H. D. Hosgood Iii, D. Hoy, H. Hu, B. J. Hubbell, S. J. Hutchings, S. E. Ibeanusi, G. L. Jacklyn, R. Jasrasaria, J. B. Jonas, H. Kan, J. A. Kanis, N. Kassebaum, N. Kawakami, Y.-H. Khang, S. Khatibzadeh, J.-P. Khoo, C. Kok, F. Laden, R. Lalloo, Q. Lan, T. Lathlean, J. L. Leasher, J. Leigh, Y. Li, J. K. Lin, S. E. Lipshultz, S. London, R. Lozano, Y. Lu, J. Mak, R. Malekzadeh, L. Mallinger, W. Marcenes, L. March, R. Marks, R. Martin, P. McGale, J. McGrath, S. Mehta, Z. A. Memish, G. A. Mensah, T. R. Merriman, R. Micha, C. Michaud, V. Mishra, K. M. Hanafiah, A. A. Mokdad, L. Morawska, D. Mozaffarian, T. Murphy, M. Naghavi, B. Neal, P. K. Nelson, J. M. Nolla, R. Norman, C. Olives, S. B. Omer, J. Orchard, R. Osborne, B. Ostro, A. Page, K. D. Pandey, C. D. 
H. Parry, E. Passmore, J. Patra, N. Pearce, P. M. Pelizzari, M. Petzold, M. R. Phillips, D. Pope, C. A. Pope Iii, J. Powles, M. Rao, H. Razavi, E. A. Rehfuess, J. T. Rehm, B. Ritz, F. P. Rivara, T. Roberts, C. Robinson, J. A. Rodriguez-Portales, I. Romieu, R. Room, L. C. Rosenfeld, A. Roy, L. Rushton, J. A. Salomon, U. Sampson, L. Sanchez-Riera, E. Sanman, A. Sapkota, S. Seedat, P. Shi, K. Shield, R. Shivakoti, G. M. Singh, D. A. Sleet, E. Smith, K. R. Smith, N. J. C. Stapelberg, K. Steenland, H. Stöckl, L. J. Stovner, K. Straif, L. Straney, G. D. Thurston, J. H. Tran, R. Van Dingenen, A. van Donkelaar, J. L. Veerman, L. Vijayakumar, R. Weintraub, M. M. Weissman, R. A. White, H. Whiteford, S. T. Wiersma, J. D. Wilkinson, H. C. Williams, W. Williams, N. Wilson, A. D. Woolf, P. Yip, J. M. Zielinski, A. D. Lopez, C. J. L. Murray and M. Ezzati (2012). "A comparative risk assessment of burden of disease and injury attributable to 67 risk factors and risk factor clusters in 21 regions, 1990-2010: a systematic analysis for the Global Burden of Disease Study 2010." The Lancet 380(9859): 2224-2260.

Paes de Barros, R., F. H. G. Ferreira, J. R. M. Vega, J. C. Saavedra, M. De Carvalho, S. Franco, S. Freije-Rodriguez and J. Gignoux (2009). Measuring Inequality of Opportunities in Latin America and the Caribbean. Washington DC, World Bank. Roemer, J. E. (1998). Equality of Opportunity. Cambridge, Mass., Harvard University Press.

van Doorslaer, E., A. Wagstaff, H. Bleichrodt, S. Calonge, U. G. Gerdtham, M. Gerfin, J. Geurts, L. Gross, U. Hakkinen, R. E. Leu, O. ODonnell, C. Propper, F. Puffer, M. Rodriguez, G. Sundberg and O. Winkelhake (1997). "Income-related inequalities in health: Some international comparisons." Journal of Health Economics 16(1): 93112.

World Bank (2006). Equity and Development: 2006 World Development Report. Washington DC, World Bank. 